\section{Assistentarbeid i helsetenesta - noko å tenkje meir på}

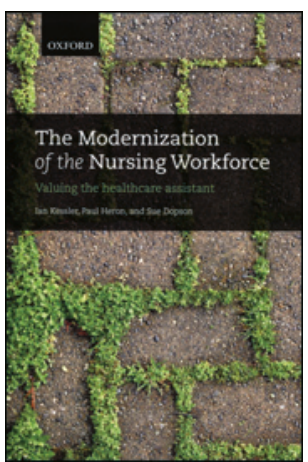

Ian Kessler, Paul Heron, Sue Dopson The modernization of the nursing workforce Valuing the healthcare assistant. 248 s, tab, ill. Oxford: Oxford University Press, 2012. Pris GBP 35

ISBN 978-0-19-969413-6

Denne boka blir ingen kioskkvelvar. Men det tyder ikkje at det er ei dårleg bok. Forfattarane presenterer forsking knytt til assistentarbeid i helsetenesta i England. Kort sagt: forsking på personellet som i store delar av helsetenesta, i England som i dei fleste andre land, står i første line i det daglege omsorgsarbeidet.

Innhaldet vil vera av størst interesse for folk som driv med helsetenesteforsking og utdanning av helsepersonell. Boka burde også kunne bli lese med utbyte av mange mellomleiarar både i kommunehelsetenesta og i helseføretaka. Språkføringa er grei, utan særleg mykje spesifikk fagterminologi.

I den første bolken gjev forfattarane eit grundig og systematisk oversyn over den metodiske tilnærminga som forskarane har brukt $i$ arbeidet sitt. Dette er stoff med eit allment perspektiv, som også kan nyttast til å strukturere liknande forskingsprosjekt utanfor England. I eit internasjonalt perspektiv er truleg denne utviklinga av modellar og eit rammeverk for forsking det viktigaste med boka.

Den andre delen inneheld massevis av empiriske data knytte til arbeidet som «healthcare assistant». Mot slutten kjem det fire kapittel der forfattarane samlar og drøftar funna i lys av arbeidet til sjukepleiarane og assistentane sjølve, og ikkje minst assistentrolla i forhold til pasientane. Mi grove tolking av funna er at alle tykkjer vel om assistentane fordi dei utfører eit viktig arbeid. Men dei blir framleis oftast sett på som krisehjelp - nokon ein treng i mangel av nokon betre. Denne boka bør vera ei påminning om at også denne gruppa av helsepersonell bør brukast og leiast i eit meir fokusert, strategisk perspektiv, der realkompetanse på personnivå må leggast til grunn for kva oppgåver ein set helsepersonell til å gjere.

Mykje av dette kan nok også overførast til norske tilhøve. Men eg sit att med eit inntrykk av at vi her i landet har profesjonalisert assistentrolla monaleg meir enn dei har i England. Dette kjem mellom anna tydeleg til uttrykk $i$ at utdanninga som hjelpepleiar (no: helsefagarbeidar) i mange tiår har gjeve grunnlag for sjølvstendig autorisasjon som helsepersonell hjå oss. Drøftingane om ansvarsdelinga mellom sjukepleiarar og assistentar blir difor annleis her.

Eg har ikkje vore borti ei liknande bok tidlegare. Om eg hadde sett boka i ei bokhylle i ein engelsk bokhandel, hadde eg kanskje heller ikkje kjøpt den. Men den har gjeve meg noko å tenkje på, både som tilsynsførar og lærar.

\section{Nyttig pocketatlas ved klinisk undersøkelse}

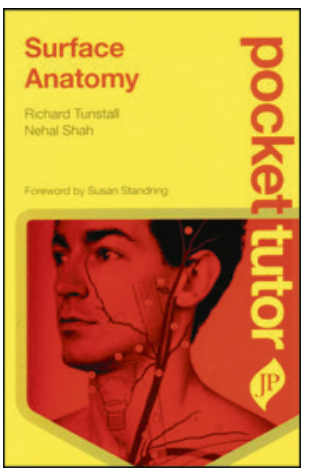

Richard Tunstall, Nehal Shah

Surface anatomy

306 s, tab, ill. London: JP Medical Publishers 2012. Pris GBP 10

ISBN-978-1-907816-17-8

Merkelig nok var topografisk anatomi en helt ubetydelig del av studiet da jeg var medisinstudent. På disseksjonssalen måtte vi lære hvert muskelfeste og hver arterie til minste forgrening, men hvordan vi skulle undersøke pasienten og finne relevante landemerker ved palpasjon, var kun viet noen få timer. I dag er medisinstudiet heldigvis mer praktisk orientert, og ved de fleste universitetene møter studentene pasienter allerede i 1. semester. En bok om topografisk anatomi bør være et obligatorisk referansemiddel ved klinisk undersøkelse av pasienten.

Surface anatomy er utgitt i pocketformat for frakkelommen, men papiret og de over 200 fargefotografiene er av høy kvalitet. Det er enkelt å finne frem takket være relevante overskrifter, og det er en god balanse mellom tekst og illustrasjoner. Tekstbokser med innhold om klinisk relevans supplerer bildene.

I kapittel 1 gir forfatterne en innføring i anatomisk terminologi, undersøkelsesteknikk, kutan innervasjon og hvordan man beskriver bevegelsesutslag hos pasienten. I de følgende kapitlene (2-8) ser de så på de spesifikke anatomiske områdene.

Jeg har nå hatt boken liggende tilgjengelig ved skadepoliklinikken i over én måned, og den er flittig brukt. Jeg har oppdaget at jeg kun bruker bildene i min kliniske hverdag. Mye av teksten kunne man egentlig ha kuttet ut - til fordel for enda større bilder. Men for studenter som fortsatt må pugge anatomiske detaljer, vil teksten være nyttig. Jeg kunne tenkt meg flere praktisk relevante illustrasjoner, for eksempel av trygge soner for injeksjoner, som intramuskulære injeksjoner i glutealregionen osv. Flere av tekstboksene med «clinical insights» - altså bokser med klinisk relevante fakta om de forskjellige regionene, er ikke så klinisk relevante - men de forstyrrer ikke det gode inntrykket.

Jeg anbefaler alle medisinstudenter og sykepleiestudenter, men også mer erfarne klinikere, å skaffe seg en bok om topografisk anatomi. Når man først blir vant til å bruke dette atlaset i stedet for et vanlig anatomiatlas, skjønner man ikke lenger hvordan man klarte seg uten det tidligere. JP Medical Publishers selger pocketutgaven til en gunstig pris, og det er forståelig at den ligger på forlagets bestselgerliste.

Bodo Günther

Kirurgisk avdeling

Stord sykehus 